\title{
IMPREGNATION OF TEAK EXTRACT AND RESINS IN RUBBERWOOD AND FAST-GROWN TEAK WOOD
}

\author{
Balfas J \\ Forest Products Research and Development Centre, Jl Gunung Batu 5, Bogor, Indonesia \\ jamalbs2000@yahoo.com
}

Submitted April 2018; accepted July 2018

\begin{abstract}
Rubberwood and fast-grown teak wood are susceptible to fungal and insect attacks. Hence, wood from these two species must be chemically treated before use. The use of most popular chemicals (borates) pose various environmental and health problems. Thus, this study examines the effectiveness of using teak extractives and resins in improving the dimensional stability, strength and durability and other characteristics of rubberwood and fast-grown teak wood. Teak extractives were extracted from teak wood sawdust by boiling in technical grade methanol. Mixtures of extractive and resin solutions were impregnated into samples of rubberwood and fast-grown teak wood. The shellac and damar used in this study were at $8 \% \mathrm{w} / \mathrm{v}$ concentration based on volume of teak extract. Effectiveness of the treatment was assessed using physical, mechanical and durability tests. Impregnated teak extract increased the weight of wood samples. Treated wood samples possessed better dimensional stability in radial or tangential directions than untreated samples. Addition of shellac and damar resin to the teak extract significantly improved dimensional stability, strength and durability of the wood samples. Multiple impregnation significantly improved the properties of samples compared with single impregnation.
\end{abstract}

Keywords: Modification, preservative, dimensional stability, strength, durability

\section{INTRODUCTION}

Wood has been used by human for various purposes including furniture and construction. Forests are the main source of wood. As the population of human increases the demand for wood also increases. Metals, plastics and composites have been used successfully in industry but they do not outperform wood. The ever increasing demand for wood led to the utilisation of secondary wood species such as rubberwood and several other plantation timbers. An increasing volume of sawn rubberwood is used for making furniture, parquet, flooring, panels and indoor building components, substituting previously well-known timber species. The major problem with rubberwood is it possesses a high sugar content which gives it low durability and high susceptibility to insect and fungal infestation (Boerhendy et al. 2015). This causes severe sap stain and mould problems in rubberwood. Similar problems were reported on fast-grown teak wood (Basri \& Wahyudi 2013, Moya et al. 2014). Hence, rubberwood and fastgrown teak wood require chemical treatment using preservatives prior to utilisation.

Boron compounds such as boric acid, borax or disodium octaborate tetrahydrate have long been known to be effective and efficient wood preservatives. These compounds are found to be highly toxic to fungi and insects (including termites) but pose problems to the environment. Concerns over the adverse effects of preservatives on the environment and human health have urged the search for more environmentally friendly wood preservatives. Studies have shown that extracts of bark and heartwood of many woody tree species have strong biological activities such as enzyme inhibition, antioxidant and antifungal activities (Asamoah et al. 2011). Extracts of Acacia mangium are known to have significant heart-rot resistance (Mihara et al. 2005). Extracts from teak heartwood contain anthraquinone which prossess strong antitermitic activity responsible for resistance of teak wood against termites (Haupt et al. 2003, Kokutse et al. 2006). Organic wood resins impregnated into coconut wood effectively improves the durability of the wood against two subterranean termites (Sukartana \& Balfas 2007). Extracts from plant biomass offer massive potential in providing alternative wood preservatives. This study examined the effectiveness of wood extracts as alternative wood preservatives to improve 
dimensional stability, strength and durability of rubberwood and fast-grown teak wood. Samples of rubberwood and fast-grown teak wood were impregnated with teak extract mixed with $8 \%$ $\mathrm{w} / \mathrm{v}$ organic resins and their performances were evaluated.

\section{MATERIALS AND METHODS}

\section{Materials}

Wood logs were taken from 25-year-old rubber (Hevea brasiliensis) and 5-year-old fast-grown teak (Tectona grandis) plantations in West Java, Indonesia. Teak wood sawdust was collected from sawn heartwood of a 60-year-old traditional (i.e. not the fast-grown strain) teak trunks in Cepu, Central Java, Indonesia. This experiment used organic resins (shellac flakes and crystalline damar) as additives to teak extracts. Technical grade methanol was used to extract teak extractives, and as solvent for diluting the two resins into solutions.

\section{Sample preparation}

Wood samples measuring $1 \mathrm{~cm}$ thick $\times 1 \mathrm{~cm}$ wide $\times 10 \mathrm{~cm}$ long were cut tangentially or radially from each rubber and fast-grown teak wood logs and used for swelling tests. Other wood samples measuring $0.5 \mathrm{~cm} \times 5 \mathrm{~cm} \times 7 \mathrm{~cm}$ and $2 \mathrm{~cm} \times 2 \mathrm{~cm}$ $\times 9 \mathrm{~cm}$ were used for biological and mechanical tests respectively. All wood samples were then oven dried at $65^{\circ} \mathrm{C}$ to a moisture content of $10 \%$. Variables observed in this study consisted of four main factors, namely, wood species (rubber and fast-grown teak), fibre orientation (radial and tangential), impregnants (teak extract, mixture of teak extract and shellac, and mixture of teak extract and damar) and impregnation cycle (one, two and three cycles). Five replicates were used in each wood property tested. Data obtained were analysed using factorial completely randomised design. When the effect of the factor was significant, the Tukey's HSD test was conducted to further assess significant differences.

\section{Teak extraction}

Teak sawdust was oven dried at $65{ }^{\circ} \mathrm{C}$ to a moisture content of $10 \%$. Dried sawdust was hammer-milled into 200-mesh wood powder. Extractives were extracted from the wood powder using hot methanol (Martawijaya et al. 2005). For the extraction, $1000 \mathrm{~g}$ wood powder and $8 \mathrm{~L}$ of methanol were put in an extractor vessel. The vessel was heated at $110^{\circ} \mathrm{C}$ for $60 \mathrm{~min}$. After cooling, the solvent and wood powder were separated through mechanical squeezing in a cold press fitted with a white cotton cloth filter. Average residual solids was $3 \%$.

\section{Impregnation}

Extracts used in the impregnation came in three compositions:

(1) methanol extract only,

(2) methanol extract $+8 \% \mathrm{w} / \mathrm{v}$ shellac resin and

(3) methanol extrac $+8 \% \mathrm{w} / \mathrm{v}$ damar resin.

All wood samples were weighed before being loaded into the 7-L vacuum-pressure vessel (Figure 1). The vessel was then covered and locked tightly prior to vacuuming for 15 min. Extracts (impregnants) were then slowly pumped into the vessel until a pressure of 12 $\mathrm{kg} \mathrm{cm}{ }^{-2}$ was reached and maintained for 1 hour. Wood samples were removed and reweighed to measure extractive and/or resin retention.

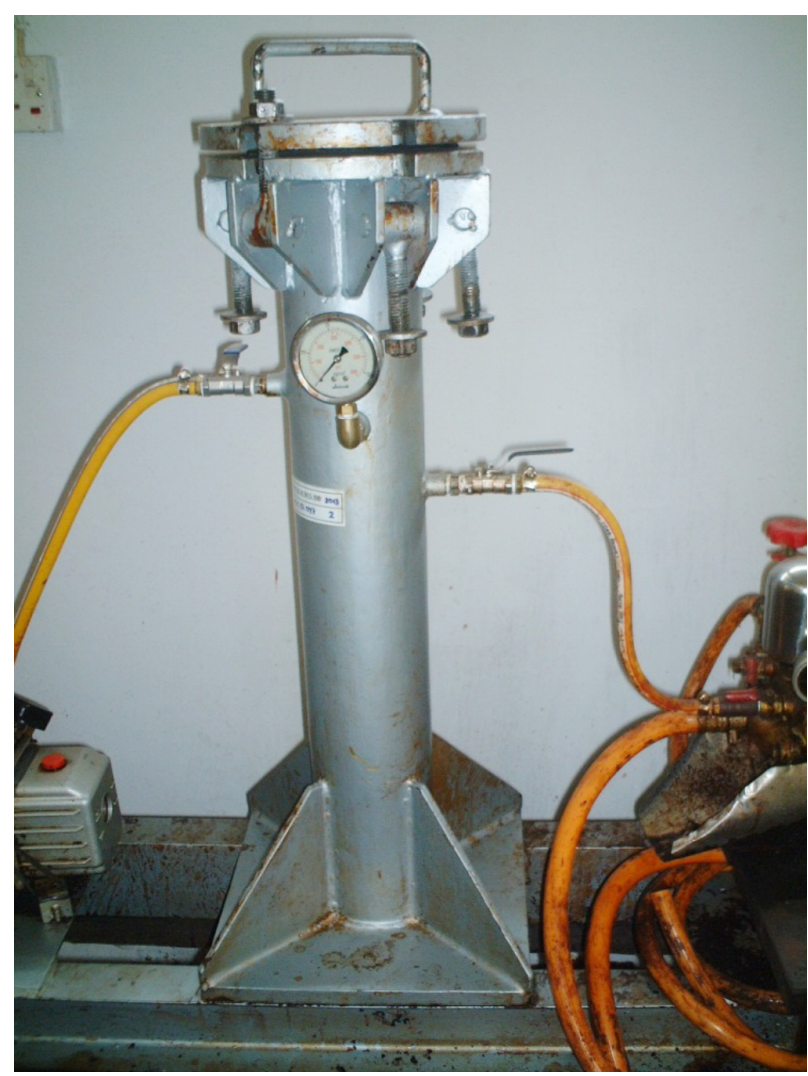

Figure 1 Vacuum-pressure vessel 
Samples were then placed in an oven $\left( \pm 65^{\circ} \mathrm{C}\right)$ and dried to a moisture content of $10 \%$. Dried treated samples were weighed again to determine their dry weights. These processes were repeated for the other two treatments, namely, teak extract and shellac mixture, and teak extract and damar mixture. The two and three impregnation cycles were conducted for above treatment.

\section{Measurements}

Dimensional changes in wood samples were measured using digital callipers. Increases in sample weight due to treatment were measured using electronic balance. Increases in the dimensions of tangential and radial samples were determined using a swellometer with dial readings recorded at six sequential immersion intervals between 5 min and 24 hours as described in Balfas (2007). Parallel and perpendicular compression strengths were determined according to the modified ASTM standard (Karnasudirdja et al. 1974). Biological laboratory wood testing against drywood termites (Cryptotermes cynocephalus) was conducted in accordance with the Indonesian Standard (SNI 2014). The Indonesian standard durability classes are categorised as follows:

\begin{tabular}{ccc}
\hline Class & Resistance & Weight loss (\%) \\
\hline I & Very good & $<3.52$ \\
II & Good & $3.52-7.50$ \\
III & Fair & $7.50-10.96$ \\
IV & Poor & $10.96-18.94$ \\
V & Very poor & $18.94-31.89$ \\
\hline
\end{tabular}

\section{RESULTS AND DISCUSSION}

Impregnation of teak extracts into the structure of wood samples brought about several changes in the characteristics of rubberwood and fast-grown teak wood. Figures 2 and 3 indicate different appearances of the control and treated wood samples. Wood samples solely treated with teak extracts were darker than the control sample, but they were lighter than samples treated with teakshellac or teak-damar mixtures. The darkening effect on the wood appearance was due to the deposition of extractives in the wood structure. The extractives contain anthraquinone, epoxies, esters and several acids (Balfas et al. 2015). The addition of shellac and damar resin into the teak extracts made the treated rubberwood and fastgrown teak wood darker (Figures 2c, 2d, 3c and $3 d$ ) compared with control (Figures $2 \mathrm{a}$ and $3 \mathrm{a}$ ) and those treated with plain teak extract (Figures $2 \mathrm{~b}$ and $3 \mathrm{~b})$.

Extractive impregnation significantly increased the weight of rubberwood and fast-grown teak wood samples. Impregnated samples experienced weight increases which varied according to species, grain orientation, extract (impregnant) type and cycle of impregnation (Tables 1 and 2). Rubberwood samples gained more weight in all treatments than fast-grown teak wood samples in both wet and dry conditions. This indicated that rubberwood was more permeable than fast-grown teak wood. Table 1 also shows that radial samples gained more weight than tangential samples. Similar observation was reported by Pallin and Petty (1981) and Cai et al. (1997). The addition of shellac to teak extracts markedly increased the weight of rubberwood and fast-grown teak wood in both wet and dry conditions (Table 1). Samples treated with mixture of teak extract $+8 \%$ damar resin consistently gained more weight than teak extract alone or in combination with $8 \%$ shellac resin. Mixture of teak extract $+8 \%$ damar has higher particulate content per unit volume since damar resin has higher specific gravity of about 1.4 while shellac, 1.1 (Farag 2010).

Wet and dry weight gain of rubberwood and fast-grown teak wood significantly decreased with increasing number of impregnation (Tables 2 and 3). The decrease may be caused first by saturation of cell walls, and then subsequently occlusion of pores with extractives following repeated impregnation (Asamoah et al. 2010, 2011). Wood samples impregnated with teakdamar mixture showed higher wet weight gain than samples impregnated with teakshellac mixture (Table 2). This trend was also observed in dry samples after the first and second impregnation treatments, but with lower values (Table 3). Though extractive content increased in dry wood samples after the first and second impregnation, drying excluded solvent especially methanol from the wood cells and wood cell walls wihch lowered weight (Haupt et al. 2003).

Impregnation of extracts and its mixtures into rubber and fast-grown teak wood samples significantly improved their dimensional stability. Figures 4 and 5 show swelling patterns of the untreated and treated rubberwood samples while Figures 6 and 7, of teak wood samples. Swelling 


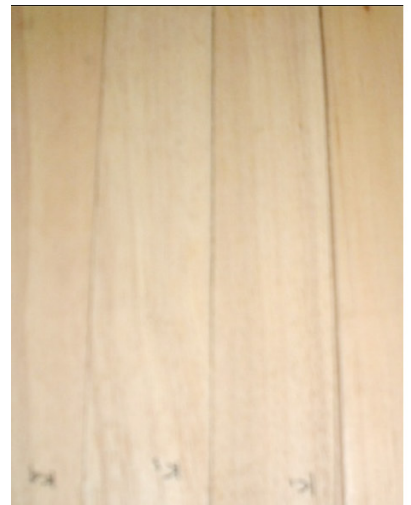

(a) Control

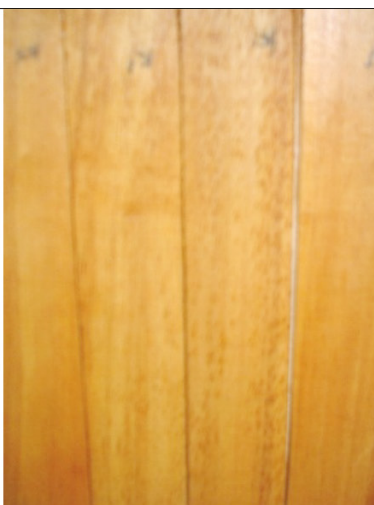

(b) Teak extract

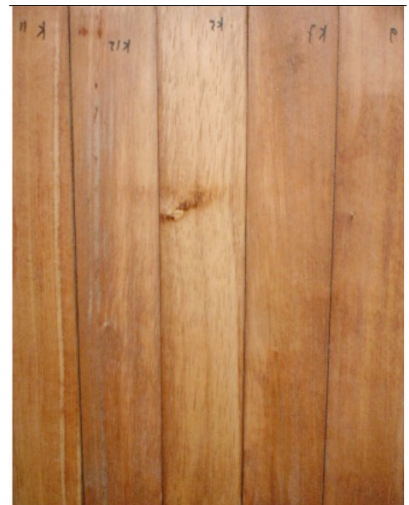

(c) Teak extract $+8 \%$ shellac

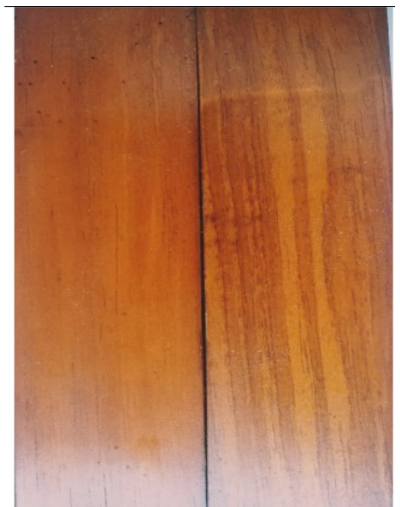

(d) Teak extract $+8 \%$ damar

Figure 2 Colour change of rubberwood before and after impregnation treatment

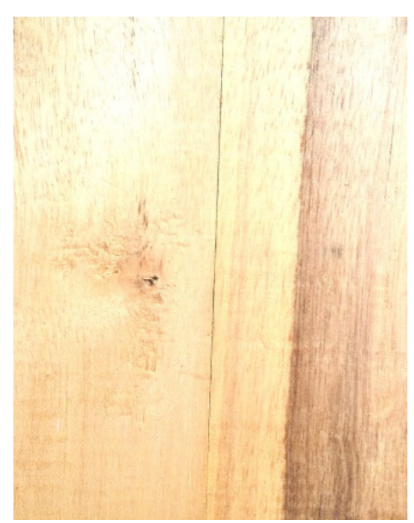

(a) Control

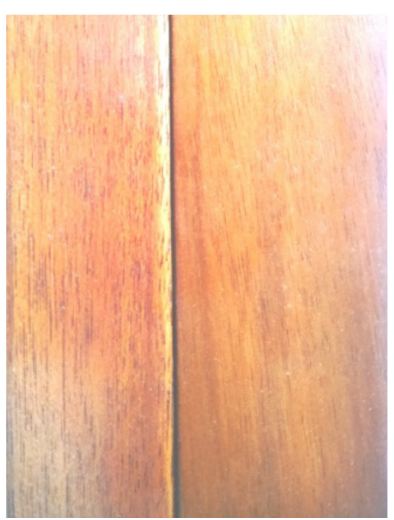

(b) Teak extract

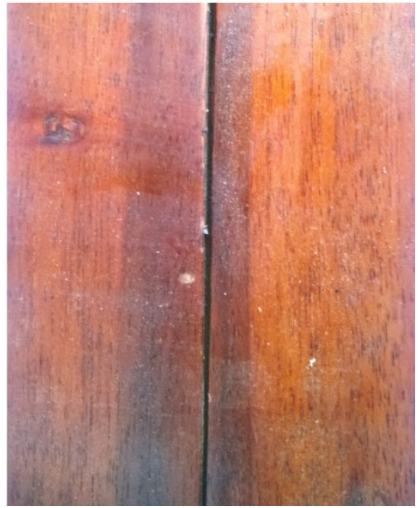

(c) Teak extract $+8 \%$ shellac

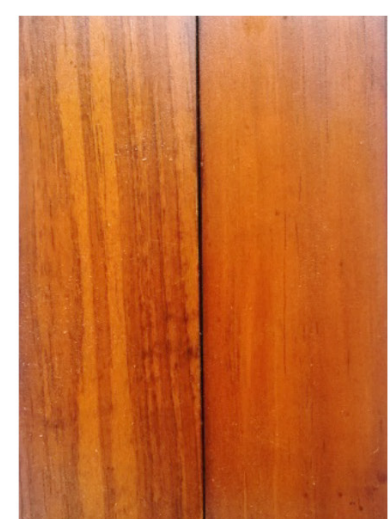

(d) Teak extract $+8 \%$ damar

Figure 3 Colour change of fast-grown teak wood before and after impregnation treatment

Table 1 Weight gain (\%) due to impregnation treatments with teak extract and resins

\begin{tabular}{|c|c|c|c|c|c|c|}
\hline \multirow{2}{*}{$\begin{array}{l}\text { Wood species and } \\
\text { sections }\end{array}$} & \multicolumn{2}{|c|}{ TE } & \multicolumn{2}{|c|}{$\mathrm{TE}+8 \% \mathrm{Sc}$} & \multicolumn{2}{|c|}{$\mathrm{TE}+8 \% \mathrm{Dm}$} \\
\hline & Wet & Dry & Wet & Dry & Wet & Dry \\
\hline \multicolumn{7}{|l|}{ Rubberwood } \\
\hline Radial & $102(9)$ & $8(0.6)$ & $144(11)$ & $11(0.6)$ & $150(12)$ & $12(0.7)$ \\
\hline Tangential & $97(7)$ & $7(0.5)$ & $125(9)$ & $10(0.5)$ & $133(10)$ & $11(0.7)$ \\
\hline \multicolumn{7}{|l|}{ Fast-grown teak } \\
\hline Radial & $91(7)$ & $7(0.4)$ & $116(8)$ & $8(0.7)$ & $128(11)$ & $10(0.6)$ \\
\hline Tangential & $76(6)$ & $5(0.3)$ & $93(8)$ & $7(0.6)$ & $107(10)$ & $9(0.8)$ \\
\hline
\end{tabular}

$\mathrm{TE}=$ teak extract, $\mathrm{Sc}=$ shellac, $\mathrm{Dm}=$ damar; values within brackets are standard deviations

Table 2 Wet weight gain (\%) in wet samples following impregnation treatment cycle

\begin{tabular}{|c|c|c|c|c|c|c|}
\hline \multirow{2}{*}{$\begin{array}{l}\text { Wood species } \\
\text { and sections }\end{array}$} & \multicolumn{2}{|c|}{ First cycle } & \multicolumn{2}{|c|}{ Second cycle } & \multicolumn{2}{|c|}{ Third cycle } \\
\hline & $\mathrm{TE}+8 \% \mathrm{Sc}$ & $\mathrm{TE}+8 \% \mathrm{Dm}$ & $\mathrm{TE}+8 \% \mathrm{Sc}$ & $\mathrm{TE}+8 \% \mathrm{Dm}$ & $\mathrm{TE}+8 \% \mathrm{Sc}$ & $\mathrm{TE}+8 \% \mathrm{Dm}$ \\
\hline \multicolumn{7}{|l|}{ Rubberwood } \\
\hline Radial & $146(11)$ & 151 (13) & 135 (12) & $137(11)$ & $125(11)$ & $121(9)$ \\
\hline Tangential & $124(10)$ & 135 (11) & $115(9)$ & $109(10)$ & $106(9)$ & $91(10)$ \\
\hline Fast-grown teak & & & & & & \\
\hline Radial & 119 (11) & $130(10)$ & $108(10)$ & $115(11)$ & $98(8)$ & $101(9)$ \\
\hline Tangential & $94(8)$ & $108(9)$ & $84(7)$ & $93(8)$ & $75(6)$ & $86(8)$ \\
\hline
\end{tabular}

$\mathrm{TE}=$ teak extract, $\mathrm{Sc}=$ shellac, $\mathrm{Dm}=$ damar; values within brackets are standard deviation 
Table 3 Dry weight gain (\%) following to impregnation cycle

\begin{tabular}{|c|c|c|c|c|c|c|}
\hline \multirow{2}{*}{$\begin{array}{l}\text { Wood species and } \\
\text { sections }\end{array}$} & \multicolumn{2}{|c|}{ First cycle } & \multicolumn{2}{|c|}{ Second cycle } & \multicolumn{2}{|c|}{ Third cycle } \\
\hline & $\mathrm{TE}+8 \% \mathrm{Sc}$ & $\mathrm{TE}+8 \% \mathrm{Dm}$ & $\mathrm{TE}+8 \% \mathrm{Sc}$ & $\mathrm{TE}+8 \% \mathrm{Dm}$ & $\mathrm{TE}+8 \% \mathrm{Sc}$ & $\mathrm{TE}+8 \% \mathrm{Dm}$ \\
\hline \multicolumn{7}{|l|}{ Rubberwood } \\
\hline Radial & $11(0.3)$ & $12(0.6)$ & $10(0.4)$ & $11(0.3)$ & $9(0.4)$ & $10(0.4)$ \\
\hline Tangential & $10(0.4)$ & $11(0.5)$ & $8(0.3)$ & $10(0.3)$ & $8(0.3)$ & $9(0.3)$ \\
\hline \multicolumn{7}{|l|}{ Fast-grown teak } \\
\hline Radial & $8(0.3)$ & $10(0.4)$ & $8(0.3)$ & $9(0.4)$ & $8(0.3)$ & $8(0.4)$ \\
\hline Tangential & $7(0.3)$ & $9(0.3)$ & $7(0.3)$ & $8(0.3)$ & $7(0.3)$ & $8(0.5)$ \\
\hline
\end{tabular}

$\mathrm{TE}=$ teak extract, $\mathrm{Sc}=$ shellac, $\mathrm{Dm}=$ damar; value within brackets is standard deviation

was least in control (Figures 4-7). Swelling of radial wood samples was less than tangential wood samples. Wood samples treated with the teak extract $+8 \%$ damar were most dimensionally stable, followed by those treated with teak extract $+8 \%$ shellac and finally, teak extract only, particularly during the early soaking period (Figures 4-7). This suggested that impregnation with mixed teak extracts produced better dimensional stability in the structure of wood. Radial and tangential rubberwood and fast-grown teak wood impregnated with teak-damar mixture swelled less than the same samples impregnated with teak-shellac mixture. Dimensional stability of wood samples decreased over time for all types of extract impregnation but swelling increased. Similar observation was reported for coconut wood treated with organic resin (Balfas 2007). Thus, plain teak extract, which does not contain moisture, is more suitable for indoor application while mixed extract treatment (teak extract $+8 \%$ damar) is better for short-term outdoor application with a better chance at preserving dimensional stability.

The positive effect of impregnation on dimensional stability is seen in the ability of the treated wood samples to have less dimensional changes in comparison with control wood samples (Rowell 2005). Samples treated with teak extract either alone or mixed with $8 \%$ shellac or damar showed little dimensional change, particularly in the early soaking periods ( 5 to $30 \mathrm{~min}$ ) (Tables 4 and 5). Swelling in treated wood samples increased with longer soaking in water. This meant that extract treatment did not protect wood structure from water intrusion with exposure for long periods of time. Thus, the treatments did not meet the requirements for long-term outdoor wood applications.
Tables 4 and 5 also show that treatment with only teak extract could not adequately improve the dimensional stability of rubberwood and fast-grown teak wood. Impregnation treatment using a mixture of teak and $8 \%$ shellac or damar showed much limited swelling than those treated with plain teak extract. However, wood samples treated with the teak-damar mixture recorded higher dimensional stability than those treated with the teak-shellac mixture. This points to the fact that resin is a wood dimension stabiliser. The higher dimensional stability of teak-damar mixture treated wood samples may be due to the higher amount of resin in the mixture and treated wood samples (Tables 1 and 2). Rubberwood intrinsically possesses higher dimensional stability than fast-grown teak wood over all soaking times (Tables 3 and 4). The difference may be attributed to the higher natural presence of water-repelling extractives such as lignin and resins in rubberwood.

Repeated impregnation cycles resulted in higher retention of teak extractive and resin in wood samples, as indicated by increasing weight gains in subsequent impregnations (Tables 2 and 3 ). The repeated impregnation cycles also increased dimensional stability of treated rubberwood (Figures 8 and 9) and fast-grown teak wood (Figures 10 and 11). Wood samples of both species of different fibre directions impregnated in one cycle had lower anti-swelling (stability) efficiency values than those impregnated in two or three cycles (Tables 2 and 3). Higher antiswelling efficiency values in wood samples after repetitive impregnation are strongly correlated with higher retention of extractives and resins in wood samples. This increased the bulk of wood and reduced intrusion of water into wood during soaking. 


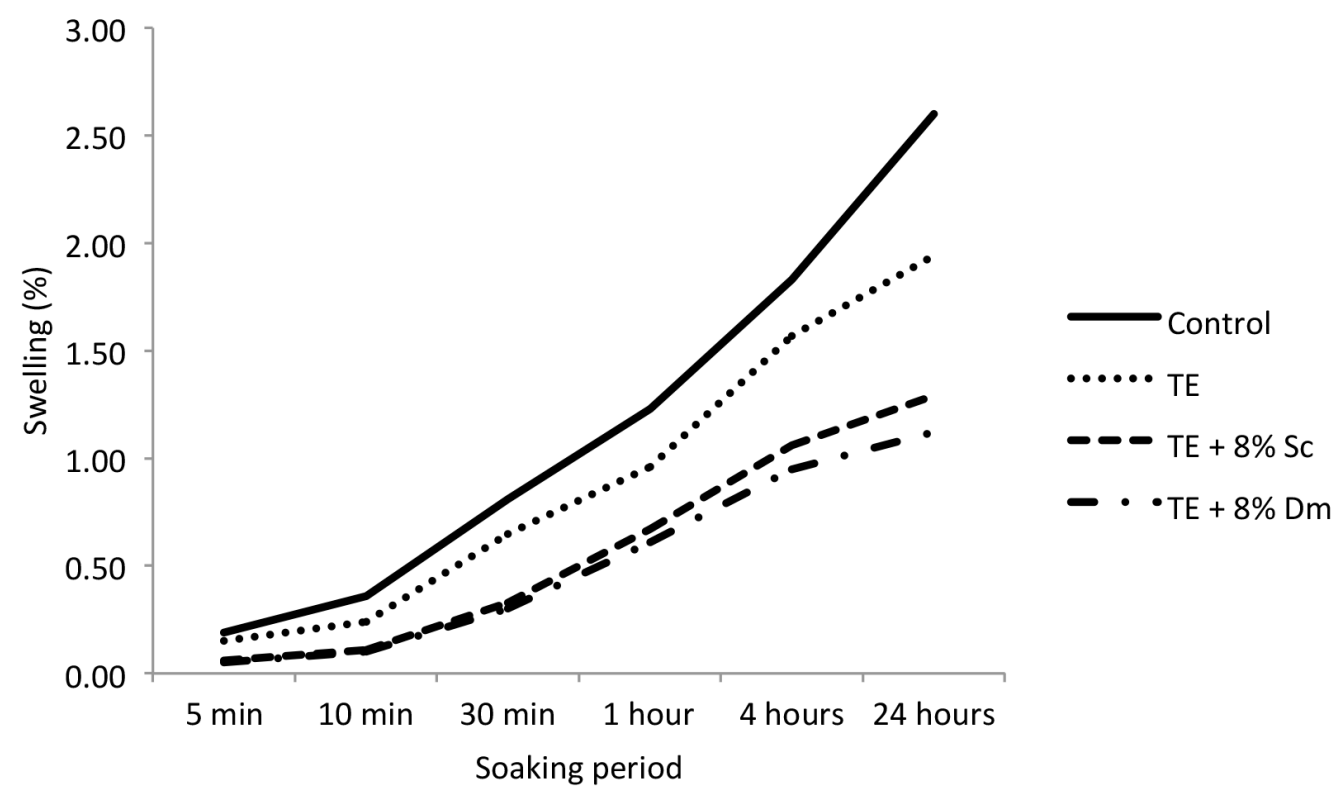

Figure 4 Radial swelling in rubberwood samples; $\mathrm{TE}=$ teak extract, $\mathrm{Sc}=$ shellac and $\mathrm{Dm}=$ damar

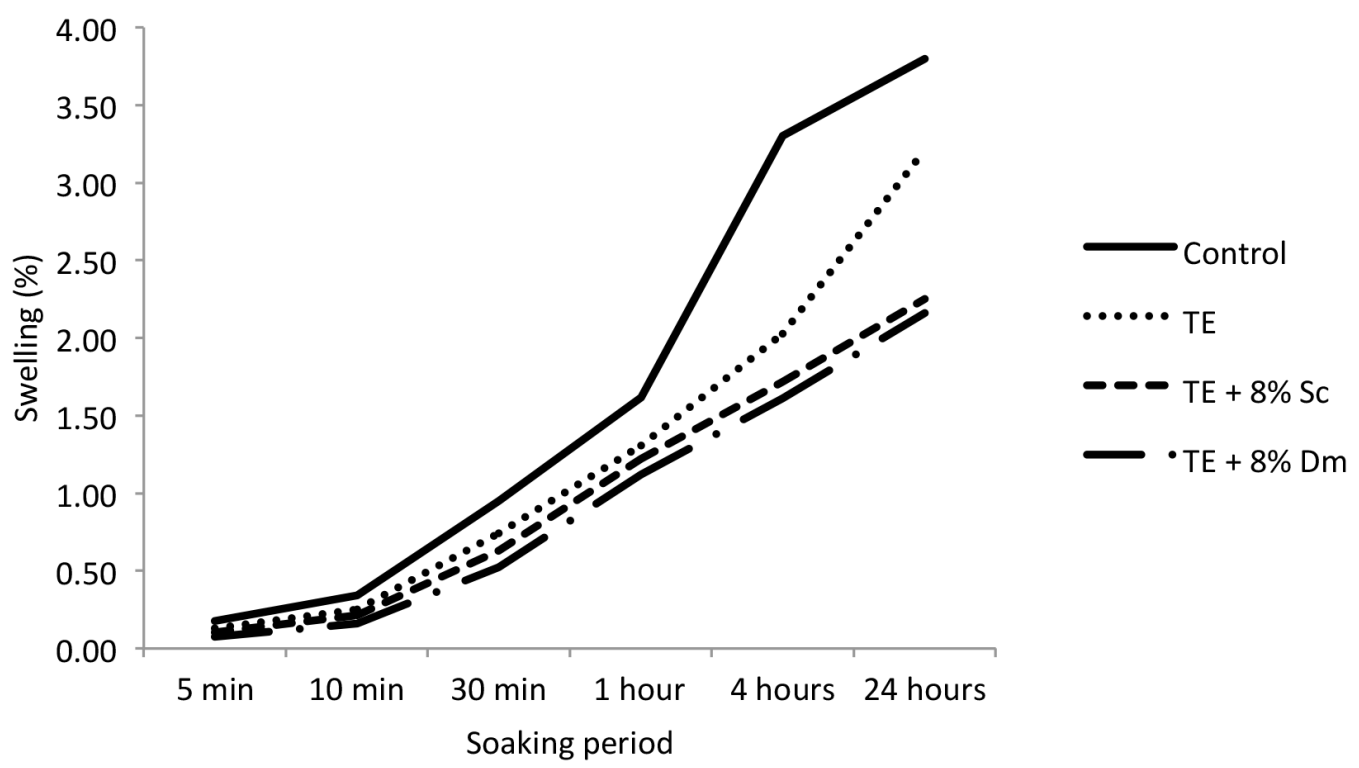

Figure 5 Tangential swelling in rubberwood samples; TE = teak extract, $\mathrm{Sc}=$ shellac and Dm = damar

Radial rubberwood samples recorded higher anti-swelling efficiency values (Figure 8) than tangential rubberwood samples (Figure 9). Similarly, radial fast-grown teak wood samples recorded higher anti-swelling efficiency values (Figure 10) than tangential fast-grown teak wood (Figure 11). Rubberwood samples recorded better anti-swelling efficiency values than fastgrown teak wood samples (Tables 4 and 5). Rubberwood may be intrinsically less permeable to water than fast-grown teak wood due to more occlusions, less pores, higher water repelling and extractives content. Higher retention of extractives and resins in rubberwood may cause it to reject water (Tables 2 and 3).

Rubberwood and fast-grown teak wood samples treated with mixed teak and resin extracts showed significant improvement in mechanical properties. Rubberwood samples treated with plain teak extract had 10 to $20 \%$ more compression strength compared with untreated rubberwood samples (Table 6) . Mechanical properties on the other hand was lower in fast-grown teak wood samples in all 


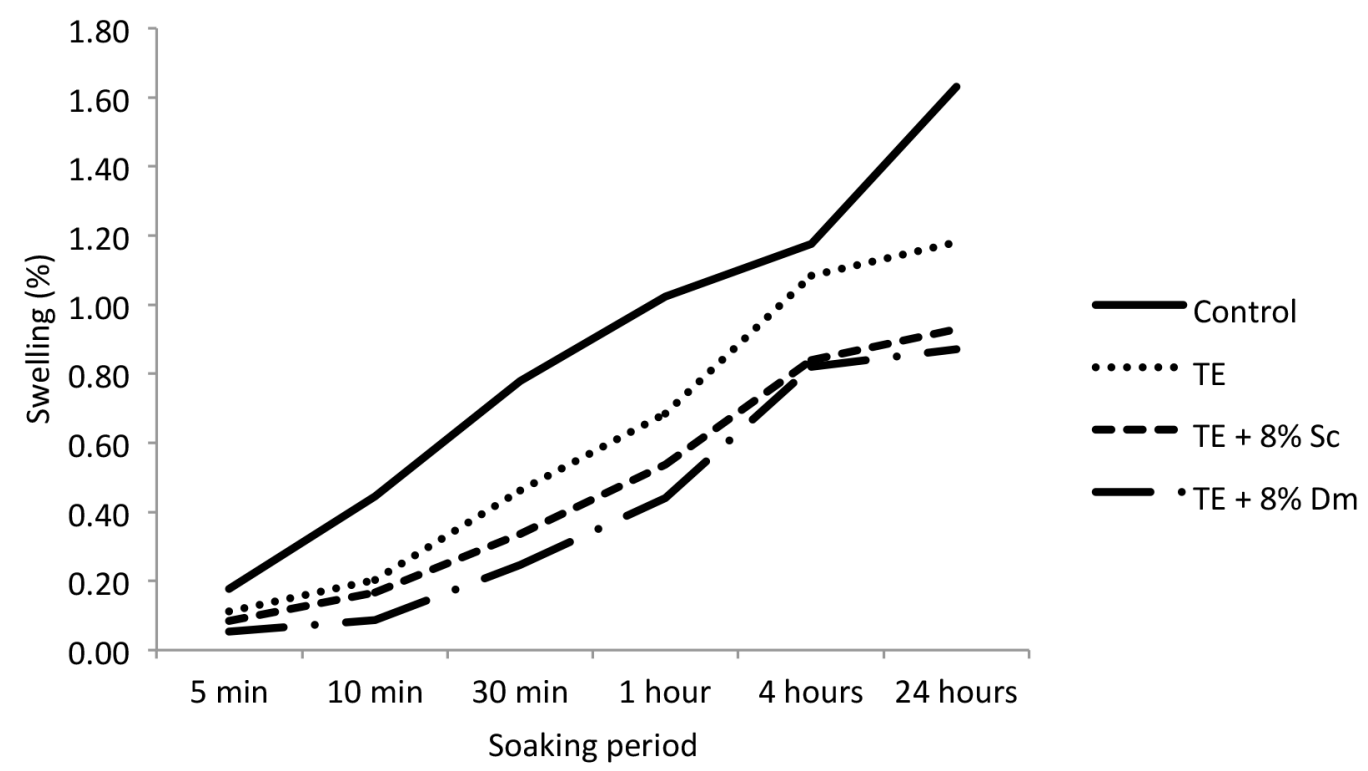

Figure 6 Radial swelling in fast-grown teak wood samples; TE = teak extract, $\mathrm{Sc}=$ shellac and Dm $=$ damar

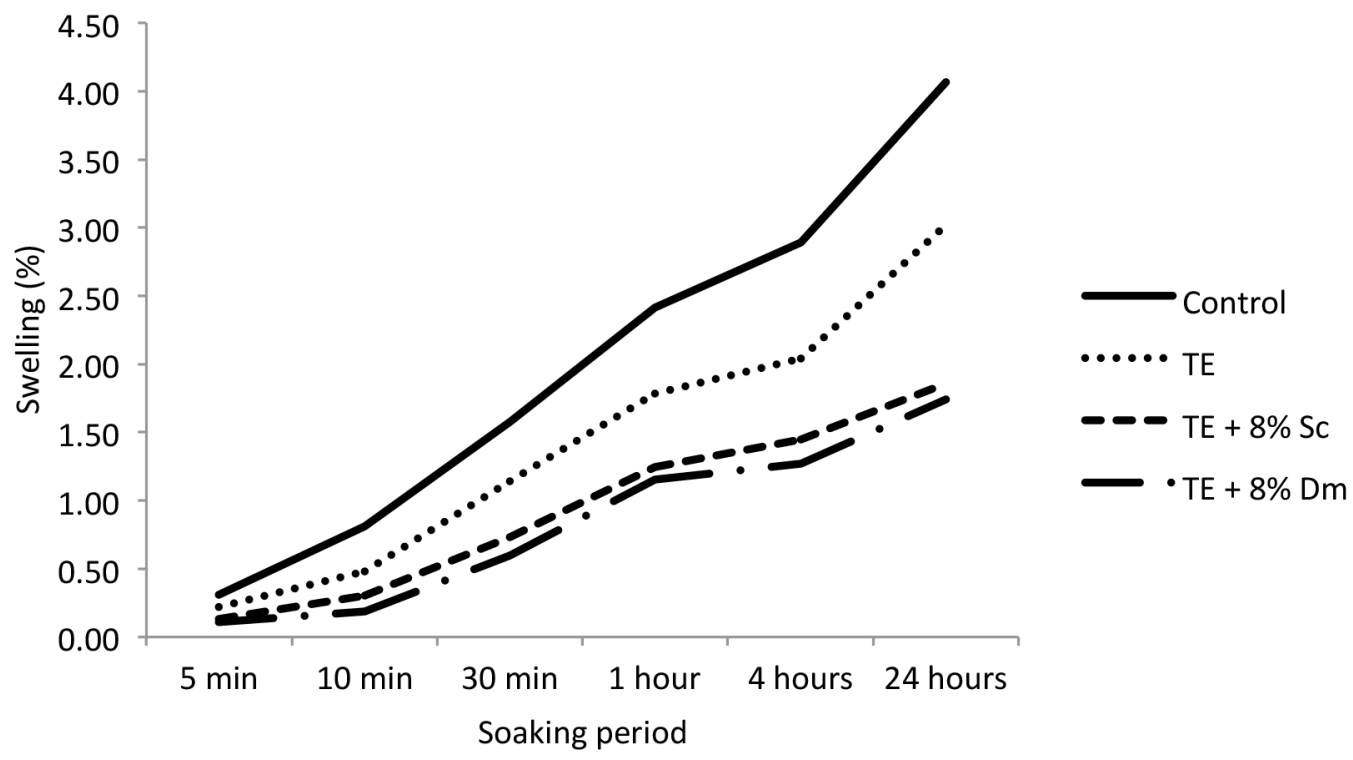

Figure 7 Tangential swelling of fast-grown teak wood samples; TE = teak extract, Sc = shellac and Dm = damar

Table 4 Anti-swelling efficiency values (\%) of treated rubberwood according to treatment, fibre direction and soaking time

\begin{tabular}{lcrrrrrr}
\hline Treatment & FD & \multicolumn{7}{c}{ Soaking time } \\
\cline { 3 - 8 } & & \multicolumn{1}{c}{5 min } & 10 min & 30 min & 1 hour & 4 hours & 24 hours \\
\hline TE & $\mathrm{R}$ & 28.87 & 19.40 & 7.41 & 5.03 & 2.63 & 0.96 \\
& $\mathrm{~T}$ & 25.65 & 17.08 & 9.30 & 4.23 & 2.81 & 0.72 \\
$\mathrm{TE}+8 \% \mathrm{Sc}$ & $\mathrm{R}$ & 78.24 & 66.51 & 52.08 & 42.61 & 34.25 & 29.57 \\
& $\mathrm{~T}$ & 70.09 & 62.36 & 44.69 & 38.60 & 30.81 & 22.54 \\
$\mathrm{TE}+8 \% \mathrm{Dm}$ & $\mathrm{R}$ & 121.32 & 102.07 & 92.74 & 76.20 & 68.52 & 52.46 \\
& $\mathrm{~T}$ & 111.25 & 96.44 & 87.25 & 67.62 & 60.15 & 50.38 \\
\hline
\end{tabular}

$\mathrm{FD}=$ fibre direction, $\mathrm{R}=$ radial, $\mathrm{T}=$ tangential, $\mathrm{TE}=$ teak extract, $\mathrm{Sc}=$ shellac, $\mathrm{Dm}=$ damar 
Table 5 Anti-swelling efficiency $(\%)$ of fast-grown teak wood according to treatment, fibre direction and soaking time

\begin{tabular}{lcrrrrrc}
\hline Treatment & FD & \multicolumn{7}{c}{ Soaking time } \\
\cline { 3 - 8 } & & 5 min & 10 min & 30 min & 1 hour & 4 hours & 24 hours \\
\hline $\mathrm{TE}$ & $\mathrm{R}$ & 23.48 & 17.35 & 8.81 & 4.72 & 2.32 & 0.69 \\
& $\mathrm{~T}$ & 21.70 & 15.44 & 8.62 & 4.08 & 2.24 & 0.42 \\
$\mathrm{TE}+8 \% \mathrm{Sc}$ & $\mathrm{R}$ & 72.85 & 62.62 & 48.62 & 40.25 & 31.46 & 27.90 \\
& $\mathrm{~T}$ & 68.47 & 57.04 & 41.21 & 35.73 & 28.55 & 21.84 \\
$\mathrm{TE}+8 \% \mathrm{Dm}$ & $\mathrm{R}$ & 115.37 & 97.08 & 89.63 & 72.48 & 63.90 & 47.82 \\
& $\mathrm{~T}$ & 106.56 & 92.64 & 82.07 & 65.57 & 57.06 & 41.37 \\
\hline
\end{tabular}

$\mathrm{FD}=$ fibre direction, $\mathrm{R}=$ radial, $\mathrm{T}=$ tangential, $\mathrm{TE}=$ teak extract, $\mathrm{Sc}=$ shellac, $\mathrm{Dm}=$ damar

Table 6 Parallel and perpendicular compression strength of rubber and fast-grown teak wood

\begin{tabular}{lccccc}
\hline Treatment & \multicolumn{2}{c}{$\begin{array}{c}\text { Compress parallel grain } \\
\left(\mathrm{kg} \mathrm{cm}^{-2}\right)\end{array}$} & & \multicolumn{2}{c}{$\begin{array}{c}\text { Compress perpendicular grain } \\
\left(\mathrm{kg} \mathrm{cm}^{-2}\right)\end{array}$} \\
\cline { 2 - 3 } \cline { 5 - 6 } & Rubber & Fast-grown teak & & Rubber & Fast-grown teak \\
\hline Control & 434.70 & 229.03 & & 183.68 & 76.73 \\
$\mathrm{TE}$ & 472.39 & 225.45 & & 238.30 & 77.41 \\
$\mathrm{TE}+8 \% \mathrm{Sc}$ & 526.38 & 325.70 & & 265.04 & 90.68 \\
$\mathrm{TE}+8 \% \mathrm{Dm}$ & 552.53 & 348.62 & & 278.20 & 105.70 \\
\hline
\end{tabular}

$\mathrm{TE}=$ teak extract, $\mathrm{Sc}=$ shellac, $\mathrm{Dm}=$ damar

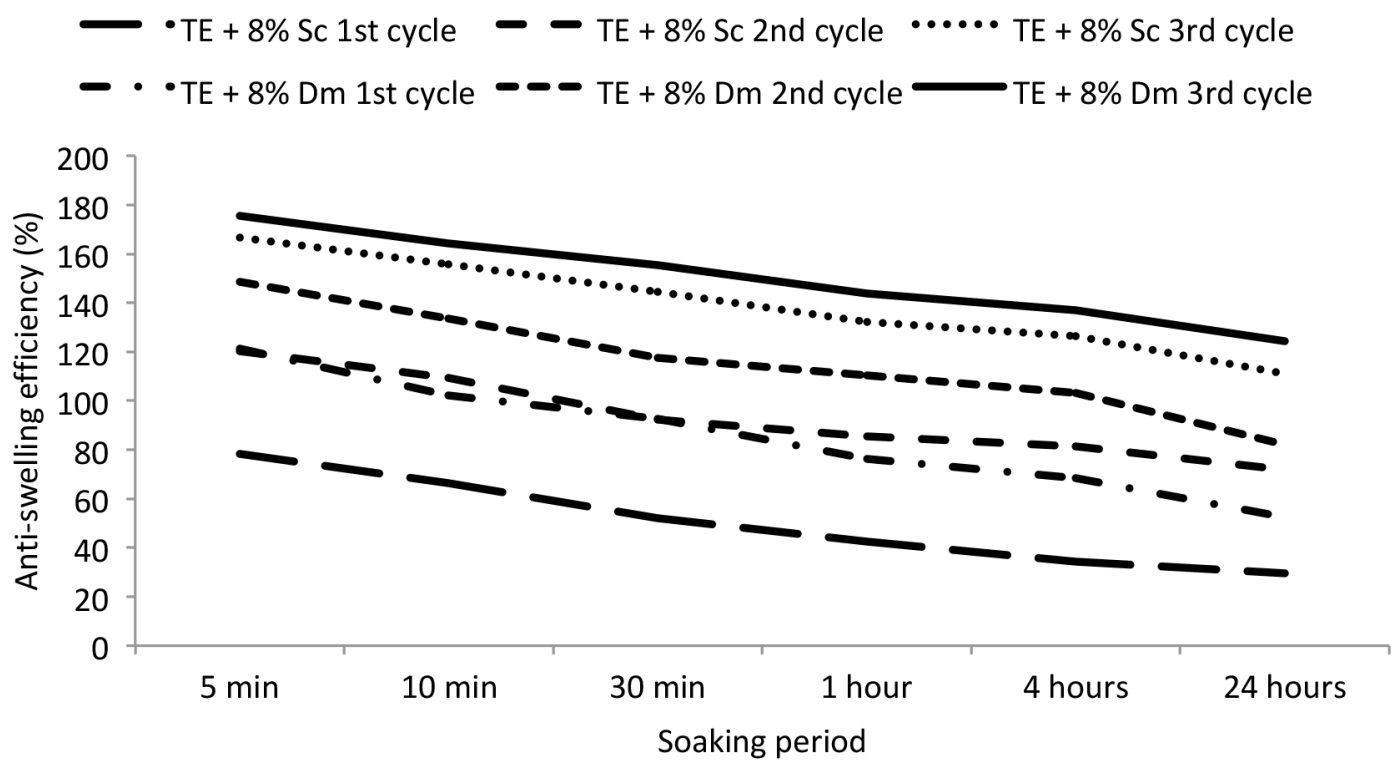

Figure 8 Anti-swelling efficiency in radial rubberwood samples; TE = teak extract, $\mathrm{Sc}=$ shellac, Dm = damar

treatments (Table 6). Rubberwood and fastgrown teak wood samples treated with plain teak extract or with mixtures of shellac and damar, recorded significantly higher (25-30\%) compression strength. Increasing retention of extractives and resins in the structure of wood following repeated impregnation could significantly improve mechanical strength (Table 7). Generally, damar mixture improved the mechanical behaviour of wood samples better than teak-shellac mixture after repeated impregnation except on the third impregnation (Table 7). In some instances, especially during temperature and/or pressure surges, repeated 


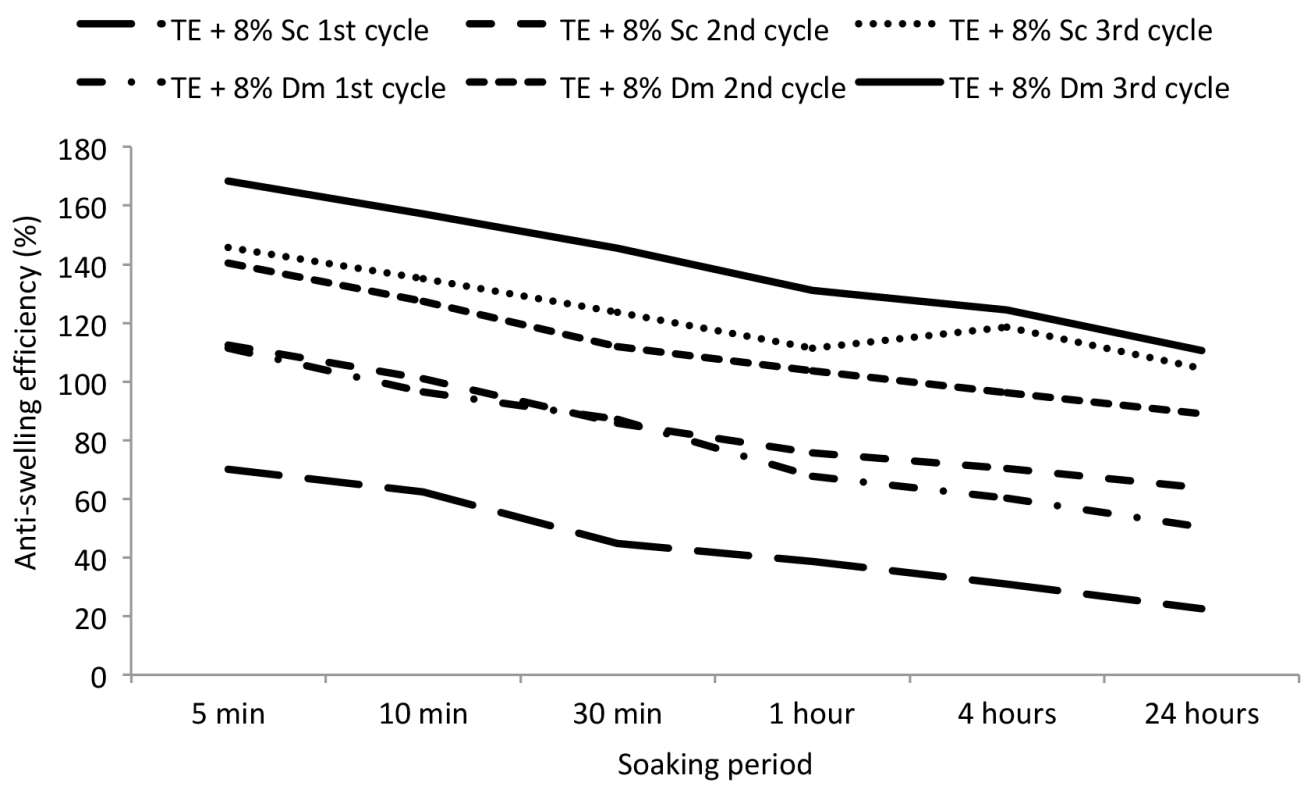

Figure 9 Anti-swelling efficiency in tangential rubberwood sample; $\mathrm{TE}=$ teak extract, $\mathrm{Sc}=\mathrm{shellac}, \mathrm{Dm}=\mathrm{damar}$

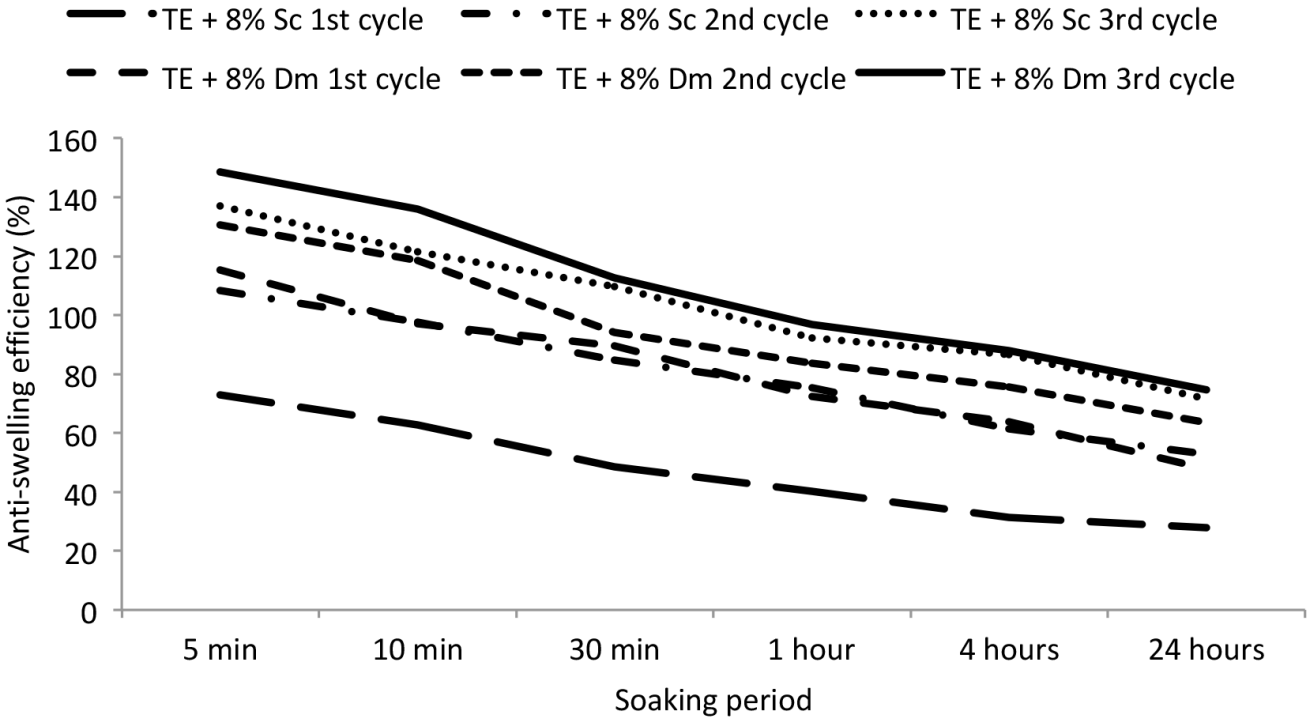

Figure 10 Anti-swelling efficiency in radial fast-grown teak wood samples; $\mathrm{TE}=$ teak extract, $\mathrm{Sc}=\mathrm{shellac}, \mathrm{Dm}=\mathrm{damar}$

or prolonged impregnation, causes wood fibre to separate, irrespective of any possible bulking, to undermine mechanical strength (Anderberg 2016). This often establishes points of weakness within the structure of wood samples which can undermine bulking (Behr et al. 2017). Effective resin retention in wood samples may have caused wood structure to bulk and fibre bonding to tighten to cause improvement in mechanical strength (Hill 2006).

Durability (resistance of wood against biological agents of deterioration) of wood samples was measured through mass loss of the wood samples under termite attack. Treated rubberwood and fast-grown teak wood fell into two higher durability classes (I and II) while control wood samples were classified into two lower durability classes (III and IV) (Table 8). The use of plain teak extracts conferred rubberwood with significant protection against termites than samples of fast-grown teak wood. Durability is cumulative, and preserved durability will always add on natural durability (Asamoah et al. 2010, 2011). Teak-shellac and teak-damar mixture 


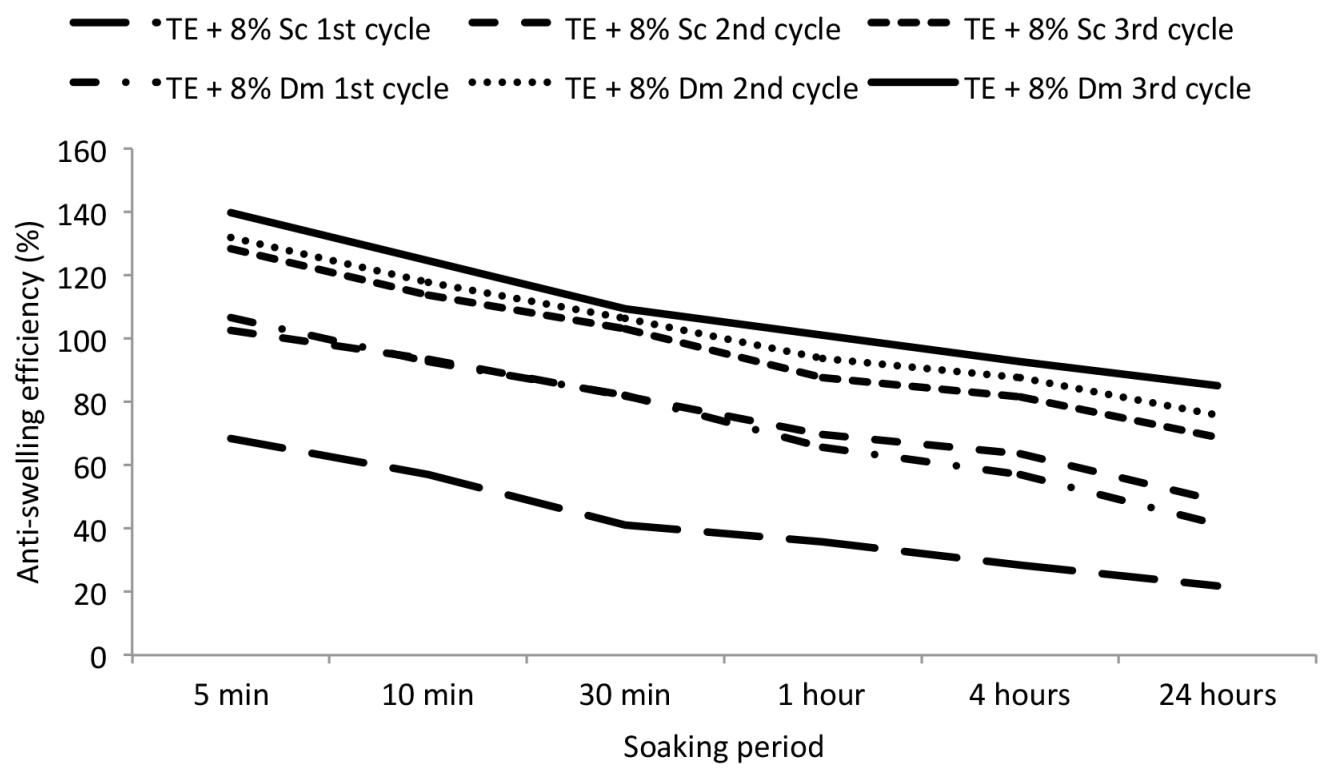

Figure 11 Anti-swelling efficiency in tangential fast-grown teak wood samples; TE = teak extract, $\mathrm{Sc}=\mathrm{shellac}$, $\mathrm{Dm}=$ damar

Table 7 Parallel and perpendicular compression strength of repeated impregnation

\begin{tabular}{lccccc}
\hline Treatment & \multicolumn{2}{c}{$\begin{array}{c}\text { Compress parallel grain } \\
\left(\mathrm{kg} \mathrm{cm}^{-2}\right)\end{array}$} & & \multicolumn{2}{c}{$\begin{array}{c}\text { Compress perpendicular grain } \\
\left(\mathrm{kg} \mathrm{cm}^{-2}\right)\end{array}$} \\
\cline { 2 - 3 } \cline { 5 - 6 } & Rubber & Fast-grown teak & & Rubber & Fast-grown teak \\
\hline TE + 8\% Sc, 1 cycle & 526.38 & 325.70 & & 265.04 & 90.68 \\
$\mathrm{TE}+8 \%$ Sc, 2 cycle & 558.07 & 346.28 & & 238.30 & 107.52 \\
$\mathrm{TE}+8 \%$ Sc, 3 cycle & 605.36 & 363.72 & & 252.18 & 125.30 \\
$\mathrm{TE}+8 \%$ Dm, 1 cycle & 552.53 & 348.62 & & 278.20 & 105.70 \\
$\mathrm{TE}+8 \%$ Dm, 2 cycle & 571.47 & 360.36 & & 294.55 & 117.42 \\
$\mathrm{TE}+8 \%$ Dm, 3 cycle & 582.46 & 372.47 & & 308.48 & 126.70 \\
\hline
\end{tabular}

$\mathrm{TE}=$ teak extract, $\mathrm{Sc}=$ shellac, $\mathrm{Dm}=$ damar

Table 8 Durability of treated and untreated wood samples against subterranean termite (Cryptotermis cynocephalus)

\begin{tabular}{lccccc}
\hline \multirow{2}{*}{ Treatment } & \multicolumn{2}{c}{ Mass loss $(\%)$} & & \multicolumn{2}{c}{ Resistance class } \\
\cline { 2 - 3 } \cline { 5 - 6 } & Rubber & Fast-grown teak & & Rubber & Fast-grown teak \\
\hline Control & 30.10 & 10.10 & & IV & III \\
TE & 4.25 & 5.80 & & II & II \\
TE $+8 \%$ Sc & 2.04 & 1.93 & & I & I \\
TE $+8 \% \mathrm{Dm}$ & 1.70 & 1.64 & & I & I \\
\hline
\end{tabular}

$\mathrm{TE}=$ teak extract, $\mathrm{Sc}=$ shellac, $\mathrm{Dm}=$ damar 
treatments gave higher termite resistance to wood samples.

\section{CONGLUSION}

Plain teak extract and those mixed with teakshellac or teak-damar mixture improved the dimensional stability, strength and durability of rubberwood and fast-grown teak wood, especially after repetitive (twice or thrice) impregnation.

\section{REFERENCES}

Anderberg S. 2016. Mechanical properties of chemical modified wood of load bearing constructions. Master's thesis, Lund University, Lund.

Asamoah A, Frimpong MK \& ANTwi BC. 2010. Efficacy of Tectona grandis (Teak) and Distemonanthus benthamianus (Bonsamdua) Extractive in Ten Less Used Timber Species. Lambert Academic Publishing GmbH \& Co. KG, Saarbrücken.

Asamoah A, Frimpong MK \& Antwi BC. 2011. Efficacy of teak (Tectona grandis) and dahoma (Piptadeniastrum africanum) heartwood water extracts on the durability of five lesser used timber species. Pakistan Journal of Chemistry 1: 2220-2625.

Balfas J, BASRi E \& JASNI. 2015. Effect of teak extractive imposition on wood characteristic improvements. Pp 378-383 in Siregar et al. Topic V: Forests and Non Timber Forest Products Proceedings of International Conference of Indonesia Forestry Researchers III. 21-22 October 2015, Bogor.

Balfas J. 2007. Perlakuan resin pada kayu kelapa (Cocos nucifera). Jurnal Penelitian Hasil Hutan 25: 108-118.

BASRI E \& WAhyudi. 2013. Sifat dasar kayu jati plus Perhutani dari berbagai umur dan kaitannya dengan sifat dan kualitas pengeringan. Jurnal Penelitian Hasil Hutan 31: 93-102. doi: 10.20886/ jphh.2013.31.2.93-102.

Behr G, Bollmus S, Gellerich A \& Militz H. 2017. Improvement of mechanical properties of thermally modified hardwood through melamine treatment. Journal of Wood Material Science and Engineering 1: 262-270. doi:10.1080/17480272.2 017.1313313 .

Boerhendy HI, Agustina DS \& Suryaningtyas H. 2015. Basic Characteristics of Rubberwood for Some Recommended
Clones in Indonesia. Indonesian Rubber Research Institute, Bogor.

Cai L, Avramidis S \& Enayati AA. 1997. Moisture sorption and movement in parallam and timber strand. Holz als Roh- und Werkstoff 55: 30-39. https://doi. org/10.1007/s001070050248.

FARAG Y. 2010. Characterization of different shellac types and development of shellac coated dosage forms. PhD dissertation, Hamburg University, Hamburg.

Haupt M, Leithoff H, Meier D, Puls J, Richter HG \& Faix O. 2003. Heartwood extractives and natural durability of plantation-grown teakwood (Tectona grandis L.) - a case study. Holz Als Roh- und Werkstoff 61: 473-474. doi: 10.1007/s00107-003-0428-z.

HiLl CAS. 2006. Wood Modification: Chemical, Thermal, and Other Processes. John Wiley \& Sons Ltd., Bangor.

Karnasudirdja S, Sofyan K \& Kusumodiwiryo R. 1974. Pedoman Pengujian Sifat Fisik dan Mekanik Kayu. Publikasi Khusus No. 20. Lembaga Penelitian Hasil Hutan, Bogor.

Kokutse AD, Stokes A, Bailleres H, Kokou K \& Baudasse C. 2006. Decay resistance of Togolese teak (Tectona grandis L.) heartwood and relationship with colour. Trees 20: 219-223. doi: 10.1007/s00468-005-0028-0.

Martawijaya A, Kartasujana I, Kadir K \& Prawira SA. 2005. Atlas Kayu Indonesia. Badan Penelitian dan Pengembangan Kehutanan, Bogor.

Mihara R, Barry KM, Caroline L, Mohammed \& Mitsunaga T. 2005. Comparison of antifungal and antioxidant activities of Acacia mangium and A. auriculiformis heartwood extracts. Journal of Chemical Ecology 31: 789-804. https://www.ncbi.nlm.nih.gov/ pubmed/16124251.

Moya R, Bond B \& Quesada H. 2014. A review of heartwood properties of Tectona grandis trees from fast growth plantations. Wood Science and Technology 48: 411-433. doi: 10.1007/s00226-014-0618-3.

Pallin AA \& Petty JA. 1981. Permeability to water of the cell wall material of spruce heartwood. Wood Sciences and Technology 15: 161-169.

Rowell RM. 2005. Handbook of Wood Chemistry and Wood Composites. CRC Press, Boca Raton.

SNI (Standar Nasional Indonesia). 2014. Uji Ketahanan Kayu Terhadap Organisme Perusak Kayu (SNI 7207-2014). Badan Standarisasi Nasional, Jakarta.

Sukartana P \& Balfas J. 2007. Daya tahan kayu kelapa yang diimpregnasi dengan resin terhadap dua spesies rayap tanah. Jurnal Penelitian Hasil Hutan 25: 303311. https://doi.org/10.20886/jphh.2007.25.4.303311. 